\title{
Intertextual Encounters between Jorge de Sena and Manuel Bandeira
}

\begin{abstract}
The aim of this paper is to analyse the echoes of the modernist Brazilian poet Manuel Bandeira in the poetry of the Portuguese writer Jorge de Sena. Following the theoretical approaches of Julia Kristeva, Harold Bloom, and Antoine Compagnon, we will analyse the mechanisms of intertextuality present in some of Sena's poems dedicated to Manuel Bandeira, such as "Poema desentranhado de um poema de Manuel Bandeira," "Nos Setenta anos do poeta Manuel Bandeira," and "Morte de Manuel Bandeira." We will discuss the concept of influence and the affinities between the two writers - who met in person and became friends as manifested in references, quotations, and the use of similar subjects. Finally, we will try to see how the intertextual dialogue with Bandeira could be one way to define Sena's original poetry and how, by describing his "master," Manuel Bandeira, Sena is able to draw his own portrait as a poet.
\end{abstract}

Keywords: affinities, intertextuality, Jorge de Sena, Manuel Bandeira, modernism

When the Portuguese writer Jorge de Sena (1919-1978) decided to go into "self-exile” in Brazil in August 1959, he already occupied an important place on the cultural scene - he had published works and collaborated on the magazine Presença [Presence] and with the Cadernos de Poesia group. This decision to leave Portugal was motivated by his involvement in the failed attempt to bring down the dictatorial regime of Salazar known as the Golpe da Sé, or the Sé Coup, planned to take place on 11-12 March 1959 (Santos 2001, 67). He lived in Brazil for six years and taught at the universities of Assis and Araraquara until 1965, when he left and moved to the US. This experience of exile in Brazil, the native land of Manuel Bandeira (1886-1968), a poet whom Sena greatly admired and who is considered a model for his poetry, would intensify, as we shall see, the presence and memory of Bandeira in Sena's work; we are dealing here with the "memory of literature" that Tiphaine Samoyault refers to as intertextuality conceived in a unified form $(2005,6)$.

Jorge de Sena's interest in Brazilian literature and culture is widely documented in his Estudos de Cultura e Literatura Brasileira [Studies on Brazilian Culture and Literature], published posthumously by his wife, Mécia de Sena. This work includes forty-eight studies, reviews, chronicles, and conference papers by Sena about and relating to Brazil. In this study, we will focus on how Jorge de 
Sena received and read one of the most important poets of Brazilian modernism: Manuel Bandeira.

Manuel Bandeira, considered one of the most prolific Brazilian poets of the twentieth century (Moraes 2017), was a multifaceted poet whose work is marked by a confluence of literary styles (from Parnassianism to modernism, passing through symbolism) that the author never fully assimilated, following instead his own distinctive literary path (Negreiros 2009, 30). Being one of the pre-eminent voices of modern Brazilian poetry, Bandeira brought informal language, everyday life, prosaic facts, and day-to-day experiences to poetry, experimenting with new rhythms and images, oscillating between genuine humour, criticism, and the metaphysical melancholy of universal lyricism. Without a doubt, the originality and authenticity of this Brazilian poet, allied to a revolutionary tendency typical of modernism, aroused the deep admiration of Jorge de Sena, which can be seen through intertextuality. Before beginning to analyse the poems and texts that testify to the dialogue between the two writers, it is therefore important for us to define in general terms the theoretical framework in which the study is rooted.

We should begin by mentioning that the concept of intertextuality as defined by Julia Kristeva in 1966 and inspired by the work of Bakhtin presents the text initially as a space where relational processes are the focus of analysis at the expense of static structures (Friedman 1991, 147). Consequently, the text emerges as the result of a dialogue between various works in an intersection between words and ideas. Thus, any text becomes an amalgamation of quotations; or rather, as Kristeva says, "any text is the absorption and transformation of another. The notion of intertextuality replaces that of intersubjectivity, and poetic language is read as at least double" $(1980,66)$. This line of thought is taken up by Laurent Jenny when he says that, "outside of intertextuality, the literary work would be quite simply imperceptible in the same way as an utterance in an as yet unknown language" $(1979,5){ }^{1}$ In his turn, Graham Allen claims that "intertextuality, one of the central ideas in contemporary literary theory, is not a transparent term and so, despite its confident utilization by many theorists and critics, cannot be evoked in an uncomplicated manner" $(2011,2)$.

Taking as our starting point, therefore, a comprehensive notion of intertextuality and the theoretical foundations of Kristeva, Bakhtin, Genette, and others, we will analyse the intertextual dialogue between Jorge de Sena and the modernist Brazilian poet Manuel Bandeira. Along with the concept of intertextuality, we will also consider the concept of influence, following Harold Bloom's thoughts, and the question of literary models, drawing on the theoretical presuppositions of Adrian

1 All translations in this article are my own unless otherwise indicated. 
Marino (1998) and Álvaro Manuel Machado (1986, 15). According to Adrian Marino, models are analogical, isomorphic constructions that correspond to the theoretical and abstract description of a structure, and that make it possible to explain the function and organization that are constants of the system while always integrating a creative function $(1998,206)$. In his turn, Álvaro Manuel Machado raises the question of the status of the literary model, distinguishing productive models from reference models $(1986,17)$. A productive model is one that provokes and awakens "literary re-creation" on the level of both writing and the history of ideas; a reference model, situated on a plane further removed from admiration or affinity, is an element that is frequently mentioned, does not fall within the fundamental nature of the work, and is not structurally assimilated but becomes above all the recollection of a vague and fragmentary vision of a whole (Machado 1994, 285).

These are, in brief, the theoretical foundations that will guide our analysis of Jorge de Sena's "encounter" with Manuel Bandeira as it is materialized through intertextuality.

\section{Encounters with Manuel Bandeira's poetry}

In the above-mentioned work entitled Estudos de Cultura e Literatura Brasileira, Jorge de Sena dedicates over fifty pages to the Brazilian poet Manuel Bandeira. According to Frederick Williams (1983), who went through the writer's library, Sena received ten books from Bandeira. The memorable first personal encounter between Jorge de Sena and Manuel Bandeira took place in London in 1957, two years before Sena went into exile. Sena recalls this meeting in a text entitled "Londres e Dois Grandes Poetas" [London and Two Great Poets], in which he reveals the emotion he felt on meeting personally such a respected poet and the fact that, on a personal level, Manuel Bandeira "the man" exerted the same charm on him as the poet did. He characterizes him as a "grand seigneur," praising his natural dignity and humility, his human warmth, and his hypercivilized attitude (Sena 1988, 122). Indeed, Manuel Bandeira, a poet who was linked to the Brazilian first modernist group and whose objective was to completely revolutionize Brazilian literature, was considered by Jorge de Sena to be “a master." In fact, in a lecture given on 25 April 1956, Sena said:

Manuel Bandeira é, para mim, como que um mestre: ou, mais do que isso, a sua poesia é como aquele banho lustral, tão raro, do qual, nas horas amargas da vida ou nos instantes mais vacilantes da poesia, saímos reanimados, reconstruídos, e no entanto, admiravelmente simplificados [...] É ele talvez o que oferece à poesia de língua portuguesa um mais puro exemplo de total libertação poética. (Sena 1988, 111) 
[Manuel Bandeira is, for me, like a master; or, more than that, his poetry is like that extremely rare lustral basin from which, in life's bitter hours or in poetry's more vacillating moments, we emerge revived, rebuilt, and yet remarkably simplified. (...) It is perhaps he who offers Portuguese poetry a purer example of poetic liberation.]

Moreover, Sena recognizes that Manuel Bandeira is not merely his master but the master of his whole generation, since he taught them that "a poesia escrita em português podia ao mesmo tempo ser libérrima e disciplinada, intelectual e puramente sensível, e embebida de uma profunda humanidade sem limites no espaço e no tempo da vida" [poetry written in Portuguese could at one and the same time be very free yet disciplined, intellectual yet purely sensible, and imbued with a profound humanity that knows no limits in space and in the time of life] (Sena 1988, 126).

This admiration is emphasized throughout the texts he wrote about Manuel Bandeira, regardless of whether they have a critical or a memorial tone. Sena reveals a profound admiration for "a lição de humildade do poeta" [the poet's lesson in humility], greatly admiring his poetic freedom, spontaneity, and close attention to the apparently most insignificant aspects of life, and considers him to be the author of a "gloriosa obra" [glorious oeuvre], full of passion and wisdom (Sena 1988, 120). One of the affinities between Sena and Bandeira is, as Maria da Natividade Gonçalves (2012, 28-31) notes, their reference to the process of writing poetry as one in which the poem emerges as a thing of essence, something that imposes itself on the conscious mind like an urgent and cathartic need from which it is not possible to escape. Another element of poetic affinity between them is the importance of visual perception as a central element in their poetry, the pertinence of light as a founding element associated with a sudden and transcendent vision. In this context, as Luís Adriano Carlos remarks, "o clarão é a metáfora da aparição súbita da poesia" [the lightning-flash is the metaphor for the sudden appearance of poetry] $(1999,32)$. Thus, the birth of poetry is like a revelation, an epiphany, just as Manuel Bandeira wrote in Itinerário de Pasárgada [Itinerary of Pasárgada]: "os versos que eu fizera em menino por divertimento, principiaria então a fazêlos por necessidade, por fatalidade" [the lines I had written as a child for fun, I then began to write out of necessity, out of inevitability] (1984, 28). Both authors perpetuate the idea of the inspired poet that permeated romanticism. Therefore, as Luís Adriano Carlos says, "o pensamento poético aparece na infraestrutura da visão. E esta aparição é a revelação do discurso como estrutura que faz ver” [poetic thought appears within the infrastructure of vision. And this appearance is the revelation of the discourse as the structure that makes one see] $(1999,39)$.

In addition to this, the intertextual process through which Bandeira's poetry finds echoes in the verses of Sena is also marked by a work of assimilation and transformation, as takes place, albeit in a different manner, in Sena's "Poema 
desentranhado de um poema de Manuel Bandeira” [Poem Extricated from a Poem by Manuel Bandeira], probably written on 18 January 1970. The intertext on which this poem by Sena is based is Manuel Bandeira's poem entitled "Pensão familiar" [Two-Star Hotel] published in 1930 in the book Libertinagem [Libertinism] - a work clearly influenced by the modernist aesthetic in which a poetic transposition of external reality is effected by superimposing objectivity to the detriment of the subjectivity of the "I." The central focus of this humorous and satirical poem is a kitten that "faz pipi" [takes a piss] and covers up the "mijadela" [puddle] (Bandeira 1993, 91; trans. Slater 1989, 73). What is noticeable is Bandeira's use of a type of language that crosses the boundaries of colloquialism as it is almost coarse - in fact, the modernist's concern with the use of freer language, drawn from everyday life, is clearly evident. After having been compared to a waiter, the kitten's attitude is considered to be superior to that of humans as "sai vibrando com elegância a patinha direita:/ É a única criatura fina na pensãozinha burguesa” [he goes off, elegantly shaking his right paw/ - the only superior creature in the little twostar hotel] (Bandeira 1993, 91; trans. Slater 1989, 73). In this respect, we become aware of Bandeira's criticism, impregnated with irony and humour, of the bourgeois society of the time. In the same way, a sarcastic tone also runs through the poem that Jorge de Sena “desentranha” [extricates] from Bandeira's and which is summed up in two lines constructed around a chiasmus: "Um gatinho faz pipi/ Um pipi faz gatinho" [A kitten takes a pussy's piss/ A pussy makes a kitten] (Sena $1980,21)$. This suggests the erotic dimension of procreation, attributing to the text a different and original perspective and theme. As Ana Paula Mendes and Graça Cruz point out, we can find in this poetic experience with its concretist tone "a morphophonemic playfulness, developed through the homophonous power of language," through the chiasmus just mentioned (1992, 316). In this case, the quotation is reintegrated and transformed in the text that receives it. This follows the line of thought of Antoine Compagnon, who develops the idea of quotation as a model of all literary writing since the work of writing is rooted in "rewriting" and endowed with the capacity to unite the dispersed elements in one coherent and continuous whole $(1996,39)$. According to Renate Lachmann,

in order to describe intertextual reference to elements of other texts, a metonymic type would have to be distinguished from a metaphorical one, with the help of rhetorical categories. The appropriation of texts occurs differently according to whether they are in a relation of contiguity or a relation of similarity. (Lachmann 2008, 305)

Here, then, in Jorge de Sena's works, we can note a metonymic tendency in the use of quotations, hidden allusions, and so on.

As a result, the intertextual process by which Bandeira's poetry has echoes in Sena's is also manifested in dedications. According to Genette, they are part of the 
paratext of a work and establish a private, intellectual relationship, real or symbolic, that serves the work as an element that enhances its value or as a topic of comment (1982, 138). In effect, Sena dedicated several poems to Manuel Bandeira that we will mention here: "Nos Setenta anos do poeta Manuel Bandeira" [On the Seventieth Birthday of the Poet Manuel Bandeira] (Sena 1988, 67), "Nos Setenta e cinco anos do poeta" [On the Seventy-Fifth Birthday of the Poet] (71), "Morte de Manuel Bandeira” [Death of Manuel Bandeira] (109), and "Meditação em King’s Road” [Meditation on King's Road] (43). These dedications therefore mark important moments in Sena's personal meetings with Manuel Bandeira (in the case of "Meditação"), or their poetic encounter (through the evocation of two important birthdays and Bandeira's permanence and importance even after his death). Of the poems cited above, it is pertinent to look at the poem entitled "Nos Setenta anos do poeta Manuel Bandeira,” dated 19 April 1956, because of its theme. This poem focuses on the theme of growing old and death, and considers that the voice of the poet overcomes this circumstance of the human condition: "A tua voz, ó poeta, não pode envelhecer,/ se envelhecer é não sentir as graças da linguagem" [Your voice, poet, cannot grow old,/ if growing old means not to feel the graces of language] (Sena 1988, 151). Following this, the intertextuality that impregnates Bandeira's poetry is evoked; in other words, and speaking generally, all the other poetry on which it is based is evoked, although names are not mentioned and mention is only made of "outros que viveram, que sofreram, que/ escreveram versos quais os teus resumem" [others that lived, that suffered, that/ wrote verses which yours summarize] (Sena 1988, 151). Importance is therefore given to the knowledge that has been acquired by reading throughout the history of literature. Shelley's idea that "poets of all ages contributed to one Great Poem perpetually in progress" (Bloom 1997, 19) is brought to mind. Nevertheless, in addition to the recognition of a synthetic work of universal poetry in which the past enriches the present in a continuous historical flow, Bandeira is also recognized for his capacity for poetic innovation and transformation. Therefore, as Sena says, always addressing his interlocutor, the poet Manuel Bandeira, in a constant dialogue:

toda a poesia a ti concorre, toda,

e tu, singelo e humilde, sábio e juvenil,

a pegas delicado em teu fervor sem mácula,

e a ressuscitas nova, em português, eterna. (Sena 1988, 151)

[all poetry comes to you, all,

and you, simple and humble, wise and young,

take hold of it delicate in your unsullied fervour,

and resuscitate it anew, in Portuguese, eternal.] 
Here we find a clear allusion to Manuel Bandeira's innovative power of synthesis and transformation. His work thus becomes new and universal, starting from the poetic tradition ("toda a poesia a ti concorre" [all poetry comes to you]). The word "ressuscitas" [resuscitate] alludes to the originality and poetic renewal brought about by the Brazilian poet and also emphasizes the eternal nature of Bandeira's poetry, which the lyrical subject addresses while also revealing the single and unique tenor of his own voice:

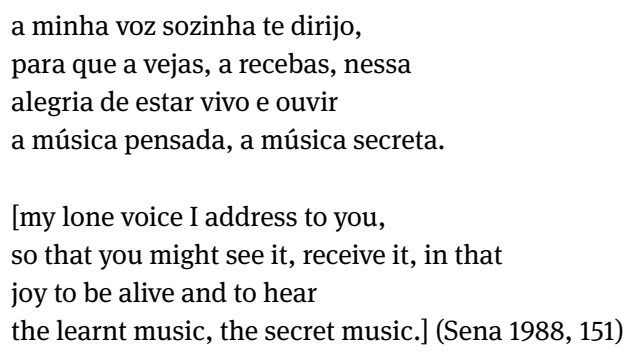

As Francisco Cota Fagundes $(2009,80)$ points out, this poem goes beyond the mere aim of portraying the poet Manuel Bandeira. It is constructed in a fusion of the portrait of the master and the self-portrait of the lyrical subject in that the poem has themes running through it - the "joy to be alive," music, solitude that could be incorporated within Sena's cosmovision. The idea of a solitary "I" inhabited by the feeling of an ontological exile is emphasized. Finally, the poem ends with the vocative "Amigo e Mestre" [Friend and Master], both capitalized, expressing profound gratitude for the poet's legacy and commitment:

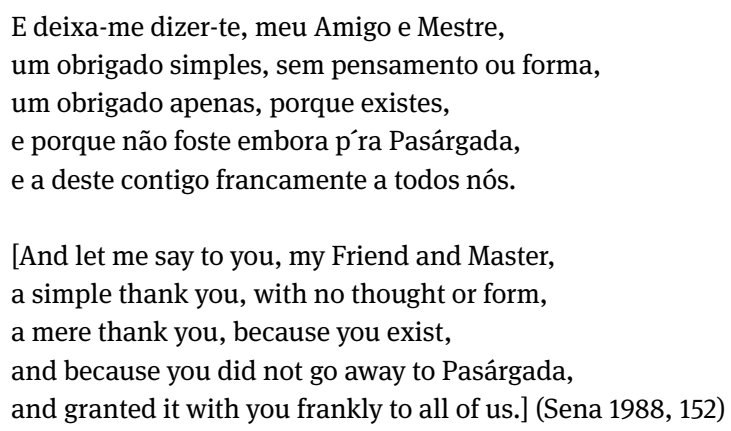

In the excerpt quoted above, we should also underline Sena's acknowledged gratitude for the fact that Bandeira did not go to Pasárgada - a desire revealed in the poem "Vou-me embora para a Pasárgada" [I'm heading off to Pasárgada], which is also part of the work Libertinagem, in which the poetic subject reveals the ironic 
elusiveness of a dream that is impossible to fulfil through escapism (a much-appreciated Romantic aesthetic) and the desire to take refuge in a perfect place, in a city where he can make use of the benefits of the technological evolution corresponding to modernist tastes: "Em Pasárgada tem tudo/ É outra civilização/ [...] / Tem telefone automático/ Tem alcalóide à vontade” [Pasárgada has all you could want/ (Another civilization [...]. ) / (...) / they've got dial telephones./ They are plenty of good-looking hookers/ just waiting for someone to hold] (Bandeira 2013, 90; trans. Slater 1989, 105). In effect, this poem, which has become one of Bandeira's most famous works, clearly reveals his capacity for innovation, since this desired paradise has sui generis characteristics that distance it from the pleasant rural space idealized by the neo-classical poets, and so it becomes the space of Freedom.

Later, Sena wrote a poem dated 15 May 1961 called "Nos Setenta e cinco anos do poeta." There is no reference in the title to Manuel Bandeira's name, which thus serves to emphasize his importance in Sena's universe and his status as a literary model - he is not a poet, but rather "the poet." However, in the second stanza we come across an allusion to the "poet of Pasárgada." This allusion to the imaginary city - although the name was originally that of a city founded by Cyrus, king of the Persians - converted by Bandeira into the space of Freedom clearly identifies to whom the poem is addressed.

In addition, the last two lines accentuate the lasting nature of Bandeira's writing as well as the ontological act of writing, here permeated by the antithetical life-death combination: "Porque escrever é morte, mas o escrito,/ se o foi por ti, Manuel, não morre mais" [Because to write is death, but what is written,/ if it was by you, Manuel, dies no more] (Sena 1988, 152). Consequently, Bandeira's writing is considered immortal, remaining as an echo of life after death.

\section{Conclusion}

Through the presence of Manuel Bandeira in Sena's poetic work, we have looked at how literary memory can be traced through mechanisms of intertextuality, or, in other words, following Samoyault's line of thought, how literature feeds on literature itself $(2005,15)$. Intertextual behaviour marked by profound admiration is clearly demonstrated, for example, in the dedications. Thus, Manuel Bandeira is inscribed in Sena's work as a reference model (Machado 1986, 90). Despite the clear affinities, the reception of Bandeira's work does not correspond to an authentic influence if we understand the latter as "assimilation inside the creative process itself and the profound transfiguration of the influencing elements" 
(Machado 1986, 91). In this case, the existing "influence" can only be conceived, as Nietzsche or Emerson described it (see Bloom 1997, 20), as "vitalization," and never as imitation or a shadow that darkens originality or poetic freedom.

On the other hand, the image constructed of the "master," Manuel Bandeira, in the poems Sena dedicates to him, is woven by means of ideas, feelings, and themes (such as growing old and death) that are transposed from Sena's poetry to Manuel Bandeira's. Here, a metonymic process is followed in which, at times, Sena's poetic "I" is projected into the poems dedicated to Bandeira. Thus his homage to the "master" coincides with a process of revelation and self-discovery on the part of the "disciple" faithful to the lessons of originality and freedom espoused by Bandeira. These are also evidenced by his social criticism and his interest in all that is human.

Thus, we can see that, through his unique sensibility and imagination, Sena, the multifaceted author of a vast bibliography of some eighty works, succeeds in integrating the poetic message of Manuel Bandeira, especially through the transposition of the external, of the everyday, to poetry, in a decisive dislocation of poetic attention. In fact, in his view, poetry expresses "a confrontation with life, in its circumstantiality" (Jackson 1981, 211), revealed through an interrogative discourse that blends interventionist content with confessional content and tradition with modernity - elements that also run through Bandeira's poetry. Basically, both marked a new era and a new dimension for Portuguese-language poetry, guided by an ethical value and anchored in a dream of a kingdom of Freedom.

Let us end by saying that we could therefore apply to Bandeira and Sena the words of Wordsworth in his Preface to Lyrical Ballads (1802):

In spite of difference of soil and climate, of language and manners, of laws and customs; in spite of things silently destroyed; the Poet binds together by passion and knowledge the vast empire of human society, as it is spread over the whole earth, and over all time. (quoted in Sena 1988, 120)

\section{Works cited}

Allen, Graham. Intertextuality. 2nd ed. London and New York: Routledge, 2011. The New Critical Idiom.

Bandeira, Manuel. Itinerário de Pasárgada. 3rd ed. Rio de Janeiro: Nova Fronteira, 1984.

Bandeira, Manuel. This Earth, That Sky: Poems by Manuel Bandeira. Trans. Candace Slater.

Berkeley, Los Angeles, and London: University of California Press, 1989.

Bandeira, Manuel. Estrela da vida inteira. Rio de Janeiro: Nova Fronteira, 1993.

Bandeira, Manuel. Bandeira de bolso: Uma antologia poética. Ed. Mara Jardim. Porto Alegre:

L\&PM Editores, 2013. 
Bloom, Harold. The Anxiety of Influence: A Theory of Poetry. 2nd ed. Oxford: Oxford University Press, 1997.

Carlos, Luís F. Adriano. Fenomenologia do Discurso Poético: Ensaio sobre Jorge de Sena. Oporto: Campo das Letras, 1999.

Compagnon, Antoine. O trabalho da citação. Trans. Cleonice P. B. Mourão. Belo Horizonte: Editora UFMG, 1996.

Fagundes, Francisco Cota. "No atelier literário de Jorge de Sena: (Auto)retratos do envelhecer e antecipação da morte (subsídios para o seu estudo)." Jorge de Sena, novas perspectivas, 30 anos depois. Ed. Francisco Cota Fagundes and Jorge Fazenda Lourenço. Lisbon: Universidade Católica Editora, 2009. 53-92.

Friedman, Susan. "Weavings: Intertextuality and the (Re)Birth of the Author." Literary History. Ed. Jay Clayton and Eric Rothstein. Madison: University of Wisconsin Press, 1991. 146-180.

Genette, Gerard. Palimpsestes: La littérature au second degré. Paris: Seuil, 1982.

Gonçalves, Maria da Natividade Esteves. "Manuel Bandeira por Jorge de Sena: Da poesia maior e menor." Master's diss. University of Porto, 2012.

Jackson, Kenneth D. “Jorge de Sena: Toward a Contemporary Enlightenment." Studies on Jorge de Sena, by His Colleagues and Friends: A Colloquium. Ed. Harvey L. Sharrer and Frederick G. Williams. Santa Barbara: University of California, 1981. 209-213.

Jenny, Laurent. “A estratégia da forma." Intertextualidades, Poétique, Revista de Teoria e Análise literárias. Trans. Clara Crabbé Rocha. Coimbra: Almedina, 1979. 5-49.

Kristeva, Julia. Desire in Language: A Semiotic Approach to Literature and Art. Ed. Leon Roudiez. Trans. Thomas Gora and Alice Jardine. New York: Columbia University Press, 1980.

Lachmann, Renate. "Mnemonic and Intertextual Aspects of Literature." Cultural Memory Studies: An International and Interdisciplinary Handbook. Ed. Astrid Erll and Ansgar Nünning in collaboration with Sara B. Young. Berlin and New York: De Gruyter, 2008. 301-310.

Machado, Álvaro Manuel. Les Romantismes au Portugal: Modèles étrangers et orientations nationales. Paris: Fundação Calouste Gulbenkian, 1986.

Machado, Álvaro Manuel. "Génio Nacional e Modelos Estrangeiros: Reflexões comparativistas sobre Miguel Torga." Aqui, Neste Lugar, e Nesta Hora: Actas do Primeiro Congresso Internacional sobre Miguel Torga. Oporto: Edições Universidade Fernando Pessoa, 1994. 285-298.

Marino, Adrian. Comparatisme et théorie de la littérature. Paris: PUF, 1998.

Mendes, Ana Paula Coutinho, and Graça Silva Cruz. "Invenções Au Gout du Jour: Invenções experimentais au goût de Jorge de Sena." Revista da Faculdade de Letras: Línguas e Literaturas 2nd ser. 9 (1992): 309-318.

Negreiros, Gil Roberto Costa. Marcas de Oralidade na poesia de Manuel Bandeira. São Paulo: Editora Paulistana, 2009.

Samoyault, Tiphaine. L'Intertextualité: Mémoire de la littérature. Paris: Colin, 2005.

Santos, Gilda "Da arte de ser multiplamente português num exílio brasileiro." Jorge de Sena, Vinte Anos Depois: O Colóquio de Lisboa, Outubro de 1988. Lisbon: Edições Cosmos, Câmara Municipal de Lisboa, 2001. 61-72.

Sena, Jorge de. Sequências. Lisbon: Moraes Editores, 1980.

Sena, Jorge de. Estudos de Cultura e Literatura Brasileira. Lisbon: Edições 70, 1988.

Sena, Mécia de. "Do exílio de Jorge de Sena no Brasil - breve avaliação." Metamorfoses 9 (2008): 123-125. 
Williams, Frederick. "Carlos Drummond de Andrade, Jorge de Sena, and International Prizes: A Personal Correspondence.” Quaderni Portoghesi 13/14 (1983): 331-358. http://www. lerjorgedesena.letras.ufrj.br/ressonancias/pesquisa/estudos/37-carlos-drummond-deandrade-jorge-de-sena-and-international-prizes-a-personal-correspondence-1/ (7 August 2015).

Dora Nunes Gago holds a PhD in Comparative Literature from the Nova University of Lisbon, Portugal (2007) and she is an associate professor of Literature at the Department of Portuguese at the University of Macau (China). Her research interests are imagology, comparative literature, Portuguese literature, and interarts studies. She is a collaborator of the CHAM and CETAPS (Nova University of Lisbon) and CLC (University of Aveiro, Portugal) research centres, and she also collaborates with the "Porta Macau" project from the University of São Paulo, Brazil. 
